Ray Costello, Black Tommies: British Soldiers of African Descent in the First World War, Liverpool: Liverpool University Press (2015), 216 pp.

Black British soldiers played a significant, yet poorly understood, role in Britain's First World War. Costello's well-researched and engagingly written study shows clearly how, while small in numbers, British born or naturalised black soldiers contributed to the war itself, as well as to life in British ports, and British officers' perceptions of race during the war years. The book is primarily envisaged as a contribution to the British historiography of the war, yet it also has much material that will interest Africanists. In particular, it provides a muchneeded metropolitan context to a growing body of research on African military service that is often conducted in isolation from the wider history of black soldiering across the Atlantic. A minority of African soldiers enrolled not in Africa, but in Britain itself, and the history of these men is often marginal to Anglophone African historiography.

Costello's study excels in bringing individual stories and voices to the fore; the lives of his subjects frequently traverse continents, moving between Africa, the Caribbean, the United States, Canada, and Great Britain. Dating from before the Great War, the case of one 'Mustapha' serves as a case in point; taken as a boy to be a mascot of the Durham Light Infantry following the Battle of Ginnis in the Sudan, Mustafa was officially enrolled into the Infantry at Mandalay in 1898 under the name James Durham, before moving to Aldershot, England, in 1902 and finally to Cork in 1905 (47). Volunteers for wartime service reveal further trans-continental ties; Melrose Goda Sishuba left his native South Africa to be educated first in New York, in 1910, before moving to Nashville, and then volunteering to fight in the South Lincolnshire Regiment during the war, before later returning to the USA, giving at least one public lecture, and then moving to South Africa to become a leader of the Ethiopian Church of South Africa (81).

The global connections of African First World War volunteers were sometimes not what they seemed; one implication of Costello's study is the variety of ways in which individuals in America and Europe imagined a wider 'black' identity during the war. Joseph Howard Lee was born in Baltimore in 1887, working as a travelling entertainer and choosing a new name of Bata Kindai Amgoza Ibn LoBagola, while claiming to have been a West African Jew who fled his home continent for Glasgow in 1896. Lee/ LoBagola joined the United States Army in August 1918, before being discharged and subsequently enlisting in the British Army, as part of a New York-based recruiting drive to find Jewish soldiers for the 38 th, 39th, and 4oth Battalion of the Royal Fusiliers (82-3). Lee/ LoBagola's multiple identities hinge on his putative West African origin, but also encompass the United Kingdom, the changing position of Jewish sol- 
diers in the British Army following the Balfour Declaration, and military service for his homeland, the USA. After the war, Lee/LoBagola finally travelled to West Africa, and Cairo.

Mobility is not the sole focus of Costello's study; he moves from introducing the context of black military service in the British Empire (1-17), to a discussion of volunteers (67-90), the British Army's exclusion of black officers and its limitation (91-112), conscription (113-132), and the problems of demobilization, particularly the 1919 riots in the United Kingdom (133-162). Costello's findings shed particular light on two matters: the status of black soldiers in the face of Britain's transition from a volunteer to a conscript military, and the ambiguous ways in which British officers defined race in decisions about commissions.

Different practices of conscription and 'voluntary' enlistment existed throughout the Empire. For example, black men were conscripted in Canada, Grenada and Jamaica from April 1917, but black recruits continued to be rejected in Britain even after the Military Service Act of January 1916. As Costello demonstrates, black men suffered 'continued rejection,' but crucially 'those who were accepted ... [relied upon] the discretion of the recruiting officer' (131). Rejection on the grounds of race did not prevent a man from subsequently being harassed as an absentee (131), nor did it prevent some individuals from being stigmatised for conscientious objection (130). Ultimately, the 'colour bar' was officially lifted in June 1918, but rejections continued into the summer of that year (132). The exclusion of black troops reveals ongoing confusion and fluidity surrounding racial categories and constructs, or as Costello summarises 'the ignorant and haphazard way in which race was treated' (131).

The avenues of promotion open to black soldiers in the British Army were severely limited; the Manual of Military Law of 1914 stipulated that Commissions should be restricted to British subjects 'of pure European descent' (92). In reality, this requirement was upheld in an arbitrary and contradictory manner. Walter Tull was commissioned a second lieutenant in 1917 (93), but the Jamaican government veterinary officer G.O. Rushdie-Gray was refused a commission, despite being recommended by the Governor of Jamaica (96). Considerable weight rested on the physical encounter between a recruit and an interviewing board, who felt themselves competent to 'see' ethnic background; visual perception appears to have been privileged when it came to deciding who was 'black' or 'white'.

Costello's book is engagingly written and will appeal to a wide readership, both inside and outside the academy. It will provide an invaluable resource for African historians who seek to understand Africans' role in metropolitan military organisations during the war. The book's discussion of the way in which notions of race informed recruitment decisions will provide a useful point 
of comparison with the deployment of 'martial race' and other constructs in colonial militaries. Costello focuses on the lives of the soldiers themselves, rather than the somewhat more arid matter of military administration; but his account highlights how many contextual factors that shaped military service in Britain, such as the military's changing systems of racial classification, remain lacunae in colonial historiography, which has instead tended instead to focus on debates about 'martial race' in colonial armies. Geographically, the work facilitates comparison of First World War military service between Britain, Africa, the Caribbean, and North America, and thus allows connections to be drawn across the Black Atlantic. A provocative but indirect implication of the book is the mobility of colonial subjects and their multiple social, intellectual, and political investments on several continents.

\section{Oliver Coates}

University of Cambridge

orc2o@cam.ac.uk 